OPEN ACCESS

Edited by:

Dina M. Bower,

NASA Goddard SFC/University of Maryland, USA

Reviewed by:

Jakob Zopfi,

University of Basel, Switzerland William Patrick Gilhooly III, Indiana University-Purdue University Indianapolis, USA

${ }^{*}$ Correspondence:

Aude Picard

apicard@fas.harvard.edu;

Amy Gartman

agartman@usgs.gov

Specialty section

This article was submitted to

Biogeoscience,

a section of the journal

Frontiers in Earth Science

Received: 09 November 2015

Accepted: 25 May 2016

Published: 15 June 2016

Citation:

Picard A, Gartman A and Girguis PR

(2016) What Do We Really Know

about the Role of Microorganisms in

Iron Sulfide Mineral Formation?

Front. Earth Sci. 4:68

doi: 10.3389/feart.2016.00068

\section{What Do We Really Know about the Role of Microorganisms in Iron Sulfide Mineral Formation?}

\author{
Aude Picard ${ }^{1 *}$, Amy Gartman ${ }^{2 *}$ and Peter R. Girguis ${ }^{1}$ \\ ${ }^{1}$ Department of Organismic and Evolutionary Biology, Harvard University, Cambridge, MA, USA, ${ }^{2}$ U. S. Geological Survey, \\ Santa Cruz, CA, USA
}

Iron sulfide mineralization in low-temperature systems is a result of biotic and abiotic processes, though the delineation between these two modes of formation is not always straightforward. Here we review the role of microorganisms in the precipitation of extracellular iron sulfide minerals. We summarize the evidence that links sulfur-metabolizing microorganisms and sulfide minerals in nature and we present a critical overview of laboratory-based studies of the nucleation and growth of iron sulfide minerals in microbial cultures. We discuss whether biologically derived minerals are distinguishable from abiotic minerals, possessing attributes that are uniquely diagnostic of biomineralization. These inquiries have revealed the need for additional thorough, mechanistic and high-resolution studies to understand microbially mediated formation of a variety of sulfide minerals across a range of natural environments.

Keywords: iron sulfide mineral, biomineralization, pyrite, mackinawite, greigite, microbial sulfate reduction, microbial sulfur disproportionation, sulfate-reducing prokaryotes

\section{CO-OCCURENCE OF MICROORGANISMS AND SULFIDE MINERALS IN NATURE}

Throughout Earth's history the burial of solid phases of Fe and $S$ has controlled the redox state of Earth's surface environments (Berner, 1984). While iron is one of the most abundant elements on Earth, sulfur represents $<1 \%$ of the Earth by mass (Allègre et al., 1995), although its importance to life and earth systems is greater than its abundance would suggest. Though the sulfur cycle was the first elemental cycle to be studied (Beijerinck, 1895), research on sulfur biogeochemistry is far from complete, and novel aspects of sulfur's transformations on Earth are still being discovered (Canfield et al., 2010). In Earth's biosphere, sulfur may be gaseous (e.g., sulfur dioxide), dissolved (e.g., sulfide, polysulfides, thiosulfate, sulfite, or sulfate) or solid (e.g., metal sulfides, elemental sulfur). Much of the interest in sulfur is due to its redox versatilityfrom sulfide $(-2)$ to sulfate $(+6)$, with numerous redox transformations possible in between (Zopfi et al., 2004). Microorganisms can take advantage of this diversity of oxidation states for energy conservation, which can be achieved by: (1) coupling the oxidation of organic compounds or dihydrogen to the reduction of oxidized organic and inorganic sulfur compounds (e.g., dimethyl sulfoxide, sulfate, elemental sulfur, and thiosulfate) (Widdel and Bak, 1992; Rabus et al., 2013); (2) disproportionating elemental sulfur, thiosulfate and sulfite (Bak and Pfennig, 1987; Thamdrup et al., 1993); and (3) oxidizing organosulfur compounds, hydrogen sulfide, sulfur, sulfite, and thiosulfate chemosynthetically with oxygen and nitrate during respiration, or by anoxygenic photosynthesis (Jørgensen and Nelson, 2004). Sulfate is the dominant sulfur species at $28 \mathrm{mM}$ in 
the modern oxic oceans, while reduced sulfur species, including hydrogen sulfide and organosulfur compounds, are often abundant where oxygen is low or absent. In these low-oxygen environments, sulfur and iron can be immobilized in the form of iron sulfide minerals, primarily the iron(II) monosulfide mackinawite (tetragonal $\mathrm{FeS}$ ), the iron(II,III) sulfide greigite $\left(\mathrm{Fe}_{3} \mathrm{~S}_{4}\right)$, and the iron (II) disulfide pyrite $\left(\mathrm{FeS}_{2}\right)$ (Schoonen, 2004; Rickard, 2012a,c).

Ninety-seven percent of the sulfide produced on Earth is attributable to the activity of sulfate-reducing prokaryotes (SRP) in low-temperature environments (Trudinger et al., 1985; Rickard, 2012b), while the remaining three percent are produced at volcanoes and deep-sea hydrothermal vents (Elderfield and Schultz, 1996; Andres and Kasgnoc, 1998). SRP are present in an enormous diversity of environments including freshwater (Ramamoorthy et al., 2009; Sass et al., 2009), hypersaline (Foti et al., 2007), hydrothermal sediment (Jørgensen et al., 1992), polar (Ravenschlag et al., 2000; Karr et al., 2006), and oceanic crust (Robador et al., 2015) habitats. Although black sulfide precipitates in anoxic sediments are used as an indicator for the presence of SRP, their abundance isn't necessarily linked to large metal sulfide deposits. There are few environmental studies closely linking microbial sulfate-reducing activity and specific sulfide minerals, even though it has been 100 years since the first suggestion that SRP might be responsible for metal sulfide ore formation (Siebenthal, 1915). In the Cu-Zn Kidd Creek Mine, the presence of SRP corresponded to the enrichment of pyrite in the sediments (Fortin and Beveridge, 1997), while in the $\mathrm{Zn}-\mathrm{Pb}$ Piquette mine, only sphalerite (ZnS) precipitated in a SRP-rich biofilm to the exclusion of other metal sulfides (Labrenz et al., 2000; Druschel et al., 2002; Labrenz and Banfield, 2004). In the Evander Au mine, $\mathrm{ZnS}$ rich biofilms were observed in association with pyrite framboids, and the minerals occurred inside organic matrices such as exopolysaccharides (Maclean et al., 2007, 2008). In sediments contaminated by mine tailing drainage, microbial cell surfaces were associated with FeS and NiS (Ferris et al., 1987). In hydrothermal vents, which result in the formation of submarine ores, both metabolically active SRP and dissimilatory sulfite reductase $(d s r)$ genes have been found in the outer walls of chimneys and in seafloor massive sulfide deposits, where seawater sulfate is entrained (Nakagawa et al., 2004; Kormas et al., 2006; Frank et al., 2013; Kato et al., 2015). Nonetheless, the role of microorganisms in sulfide mineral formation at vents is considered quantitatively unimportant, due to the abundant abiotic sulfide provided by the vents.

In low-temperature sedimentary marine environments, where microbial sulfate reduction is the most important pathway for organic matter remineralization (Jørgensen, 1982), the biogeochemical cycles of iron and sulfur are intimately linked to carbon cycling (Berner, 1982). The interactions between extracellular sulfide mineral precipitates and microorganisms are thus of great interest to understand the pathways of organic matter preservation in modern and ancient systems. For example, studies of marine sediments in Aarhus Bay in Denmark found that the highest sulfide production rates are attributed to members of the Desulfobacteraceae and that $\mathrm{Fe}_{3} \mathrm{~S}_{4}$ is most abundant in the sediment just below these communities (Leloup et al., 2009; Holmkvist et al., 2011). Although the focus of this mini review is on extracellular iron sulfide minerals, it should be noted that some magnetotactic bacteria (MTB) form intracellular iron sulfides ranging in size $35-120 \mathrm{~nm}$, that are contained in bilayer membranes within an organelle called the magnetosome (Lefevre and Bazylinski, 2013). These sulfide-mineral-forming MTB are typically found below the oxic-anoxic interface both in marine and freshwater environments, where sulfide is found in the millimolar range (Farina et al., 1990; Bazylinski et al., 1995; Simmons et al., 2004; Lefevre et al., 2011). The intracellular mineral primarily formed is $\mathrm{Fe}_{3} \mathrm{~S}_{4}$ (Posfai et al., 2013b), but tetragonal and cubic FeS have also been described as intermediate phases in the formation of greigite (Posfai et al., 1998).

Despite these discoveries in intracellular sulfide biomineralization, the role of microorganisms in the nucleation and growth of extracellular sulfide minerals is still ripe for exploration and explanation. In the next section, we examine the efforts made to understand the potential microbial mechanisms and pathways of sulfide mineral formation through laboratory experiments.

\section{EXAMINING THE ROLE OF MICROORGANISMS IN EXTRACELLULAR IRON SULFIDE MINERAL FORMATION VIA LABORATORY STUDIES}

SRP are the major producers of free sulfide in low-temperature environments, and thus have been the subject of most laboratory studies considering extracellular iron sulfide mineralization. Early studies demonstrated that $\mathrm{Fe}(\mathrm{II})$ salts react with sulfide produced in cultures of SRP, forming black precipitates, without further mineralogical characterization (Miller, 1950; Baas Becking and Moore, 1961; Freke and Tate, 1961; Temple and Le Roux, 1964). Later studies used energy-dispersive spectroscopy (EDS) in association with scanning electron microscopy (SEM) to identify the elemental ratios of iron sulfide precipitates (Table 1) (Fortin et al., 1994; Herbert et al., 1998; Benning et al., 1999; Donald and Southam, 1999; Li et al., 2004, 2006; Williams et al., 2005; Kim et al., 2015). However, determining mineralogy using EDS only can be contentious, as hydrogen sulfide can potentially adsorb onto iron sulfide aggregates, and thus alter the measured Fe:S ratio of the precipitates. X-ray diffraction (XRD), selected area electron diffraction (SAED), or X-ray absorption spectroscopy (XAS), revealed primarily the formation of mackinawite and greigite in microbial cultures to which $\mathrm{Fe}$ has been provided as soluble Fe(II) (Table 1) (Rickard, 1969; Herbert et al., 1998; Benning et al., 1999; Watson et al., 2000; Neal et al., 2001; Li et al., 2004; Williams et al., 2005; Gramp et al., 2009, 2010; Zhou et al., 2014). While greigite is typically found as rod-shaped and 100-to 300nm platelet structures (Herbert et al., 1998; Gramp et al., 2010), mackinawite does not have a specific morphology, and both minerals appear (via XRD and SEM) to be disordered and poorly crystalline and tend to assemble in $\mu \mathrm{m}$-sized aggregates (Fortin et al., 1994; Herbert et al., 1998; Benning et al., 1999; Watson et al., 2000; Kim et al., 2015). Additionally, using X-ray photoelectron 
spectroscopy (XPS), pyrrhotite $\left(\mathrm{Fe}_{1-\mathrm{x}} \mathrm{S}, 0<\mathrm{x}<0.2\right)$ has been detected in association with mackinawite (Herbert et al., 1998) or at the surface of iron oxides, when these were used in culture medium as a source of iron (Neal et al., 2001). Notably, the formation of pyrite in microbial cultures has been reported only in two instances (Rickard, 1969; Donald and Southam, 1999).

Given the limited variety of isolates investigated in these studies (Table 1), it is unclear if there is a relationship between the type of SRP and the iron sulfide minerals that form in microbial cultures. The mineralogy of iron sulfide minerals seems to differ when $\mathrm{Fe}$ is provided as soluble $\mathrm{Fe}(\mathrm{II})$ vs. when it is provided as Fe(III) minerals (Rickard, 1969; Neal et al., 2001). Also, in microbial cultures, the crystallinity of iron sulfide minerals, in particular mackinawite and greigite, increases with incubation time (Rickard, 1969; Gramp et al., 2010; Zhou et al., 2014), and with increasing incubation temperature (Gramp et al., 2010). The size of mackinawite crystals decreases when initial $\mathrm{pH}$ deviates from the optimal $\mathrm{pH}$ for growth of the strain, and the largest crystals form when the sulfide production rates are highest (Zhou et al., 2014). However, to establish whether microorganisms have a more specific role in sulfide mineral nucleation and growth, it is essential to perform control experiments by reacting free sulfide with $\mathrm{Fe}$ in the culture medium in the absence of microorganisms. Among the few studies that did such controls, sulfide was not added at concentrations or rates similar to those occurring in microbial cultures (Rickard, 1969; Donald and Southam, 1999; Neal et al., 2001; Li et al., 2004, 2006; Gramp et al., 2010). Based on comparative XRD data for biotic and abiotic control experiments, Rickard (1969) concluded that no differences can be observed between synthetic and biotic mackinawite formed extracellularly in cultures of SRP. However, when pyrite and marcasite formed in cultures, he noted the association of an oil-like material, assumed to derive from the decomposition of cells, with the minerals. Gramp et al. (2010) found no difference in the mineralogy of abiotic vs. biotic metal sulfides, but reported differences in the morphology of the iron sulfide precipitates, suggesting a role of extracellular microbial substances. Finally, Donald and Southam (1999) proposed the involvement of organic sulfur, released during cell autolysis, in the formation of iron sulfide minerals.

Microbial cell walls are highly reactive and have a net negative charge at circumneutral $\mathrm{pH}$, due to deprotonation of organic ligands contained in various polymers, such as peptidoglycan, lipopolysaccharides, teichoic acid, or murein (Beveridge, 1989). They can provide templates for metal binding and/or microenvironments for supersaturation of elements, leading to the nucleation and growth of minerals (Beveridge, 1989). Very few sulfide biomineralization studies have investigated cell-mineral associations (Table 1). Cells appear encrusted in sulfide minerals only in a few cases (Figure 1) (Fortin et al., 1994; Herbert et al., 1998; Donald and Southam, 1999; Watson et al., 2000; Williams et al., 2005). If cells interact with Fe while being metabolically inactive, then soluble Fe(II) could bind to reactive groups at the surface of cells (Figure 1A). Sulfide produced afterwards will then be able to react with iron, forming a crust of extracellular iron sulfides (Figure 1A). The apparent differences observed between Gram + and Gram - bacteria (Figure 1A) could be explained by variations among cell envelope structure and composition. Alternatively, if $\mathrm{Fe}$ is at distance from metabolically active cells, or is provided when cells have already produced sulfide, then iron sulfide minerals could precipitate away from the cells (Figure 1B). The underlying causes of the variability of cell encrustation generally remain to be addressed.

\section{UNRESOLVED QUESTIONS AND FUTURE DIRECTIONS}

If the role of microbes in metal sulfide formation is to be assessed on a broader scale, and with greater depth, the field must use microbial isolates and enrichments whose phylogeny and physiology are well characterized. Future studies should use defined rather than organic-rich and strongly buffered cultivation media, in order to mimic more closely conditions of natural environments. Additionally, while SRP essentially occupy the entire range of temperatures at which life exists, sulfide biomineralization studies have been limited to ambient pressure and temperature conditions. For example, while most sulfide mineral formation in hydrothermal environments is likely abiotically derived, the extent to which thermophilic SRP are involved remains unknown. Studies of other mineral systems suggest additional possibilities for SRP mediated mineral formation (Burns et al., 2000; Braissant et al., 2007; Gallagher et al., 2012; Zammit et al., 2015). For example, the localized microenvironments which result from SRP metabolism cause increases in $\mathrm{pH}$ and production of exopolymeric substances (EPS), which have been demonstrated to affect the morphology and mineralogy of carbonate minerals (Braissant et al., 2007). EPS may locally bind metal ions to a number of functional groups such as carboxylic acids, sulfinic or sulfonic acids, or amino acids, and the presence of metal ions in solution may also affect EPS production, resulting in a feedback between soluble metals and EPS binding (Braissant et al., 2007). In addition, SRP are not the only microorganisms that may contribute to metal sulfide mineralization. Sulfur-disproportionating bacteria that can produce sulfide and sulfate from thiosulfate, sulfite (Bak and Pfennig, 1987), or elemental sulfur (Thamdrup et al., 1993), as well as sulfide oxidizing bacteria that can excrete polysulfides (Griesbeck et al., 2000; Prange et al., 2004), both produce reduced sulfur products that may contribute to sulfide mineralization. Iron sulfides, notably pyrite, can indeed form as a result of $\mathrm{S}(0)$-disproportionation in microbial cultures and in marine sediments (Canfield et al., 1998; Finster et al., 1998; Zopfi et al., 2008). Microbially produced organosulfides and even complexation of metals by microbially-produced organic matter may also be relevant, including at conditions where high temperatures preclude direct microbial involvement.

The correct application of methods can aid in resolving the spatial distribution of microorganisms and iron sulfide minerals. The use of bulk methods, like XRD, for mineralogical characterization will remove ambiguities inherent in elemental ratio analyses such as EDS. Besides XRD, Raman spectroscopy is a powerful method for the identification of sulfide minerals 


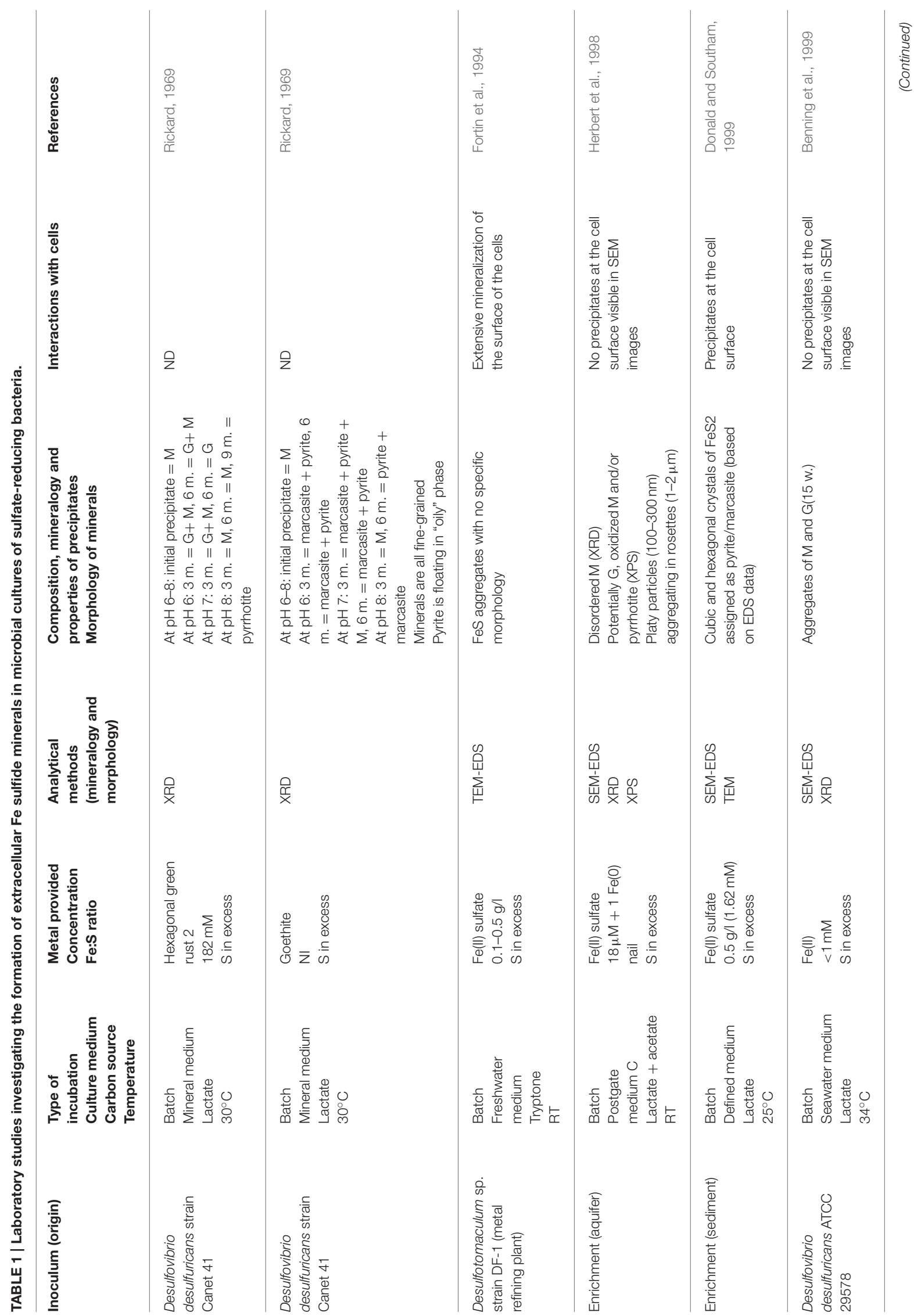




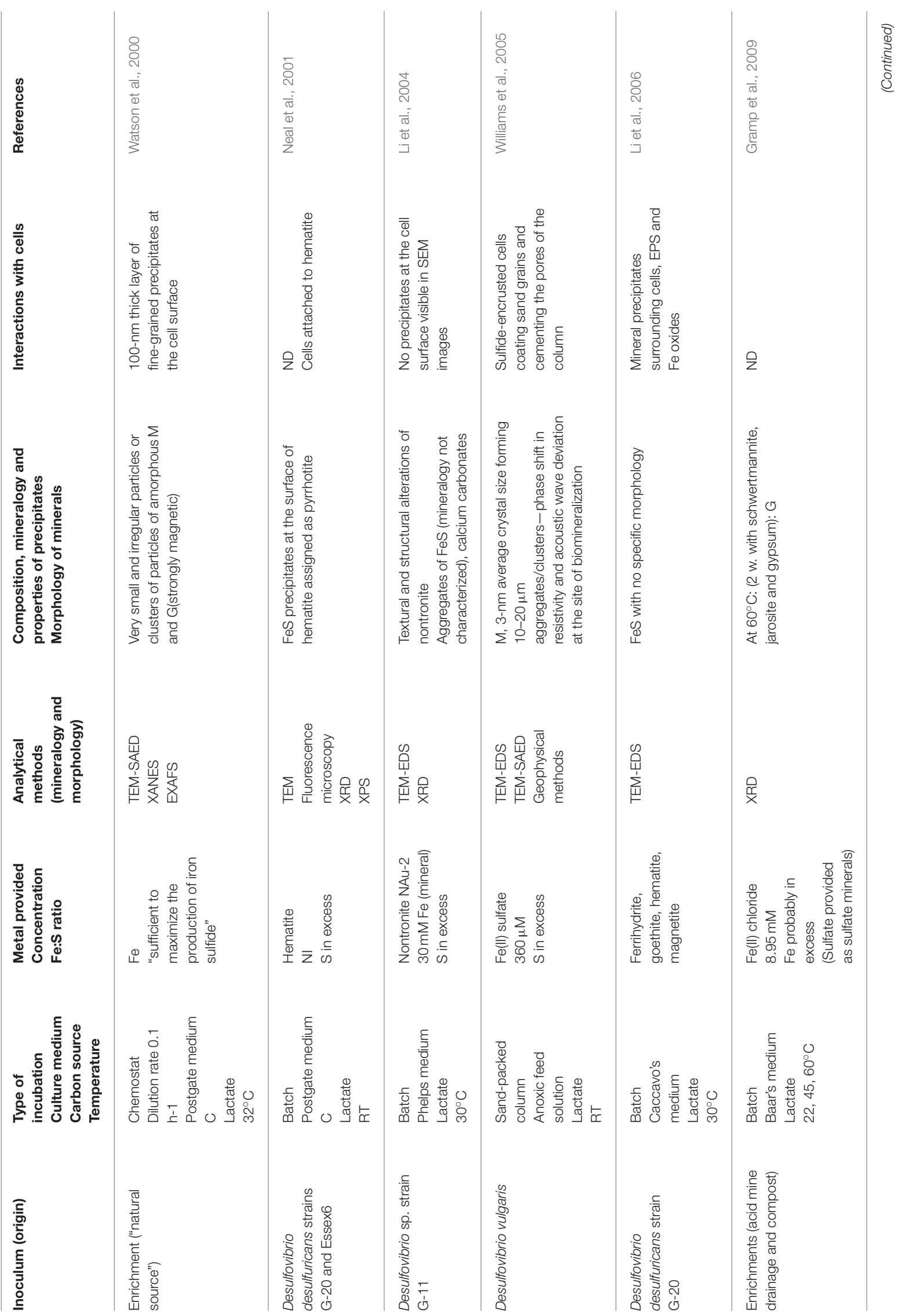




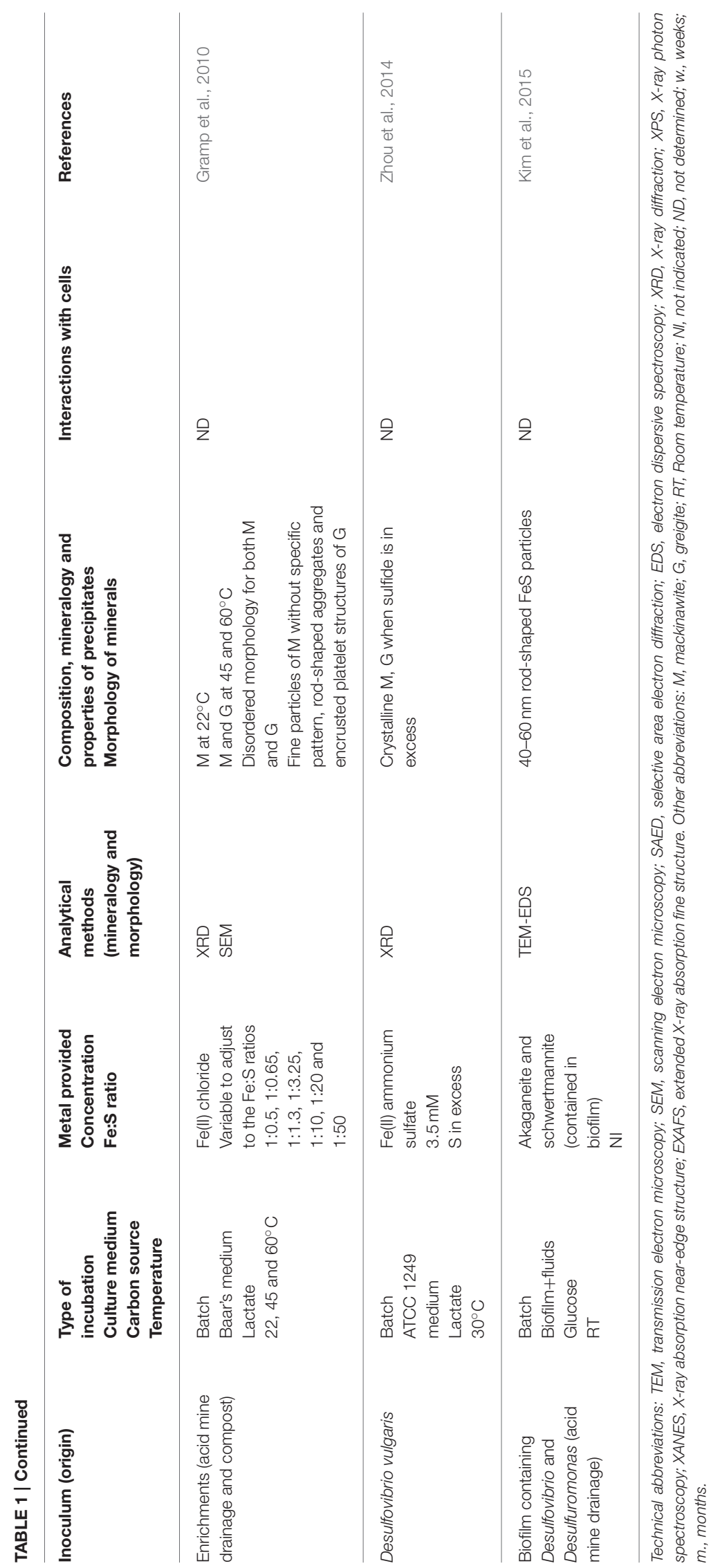


Potential biomineralization mechanisms

A Fe at proximity from cells
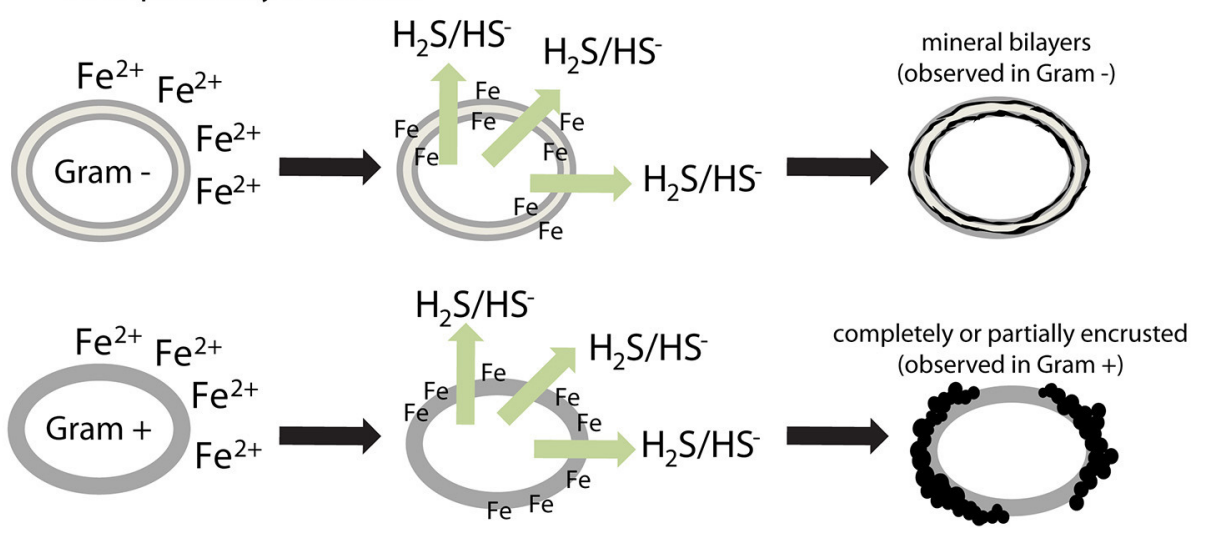

B Fe at distance from cells
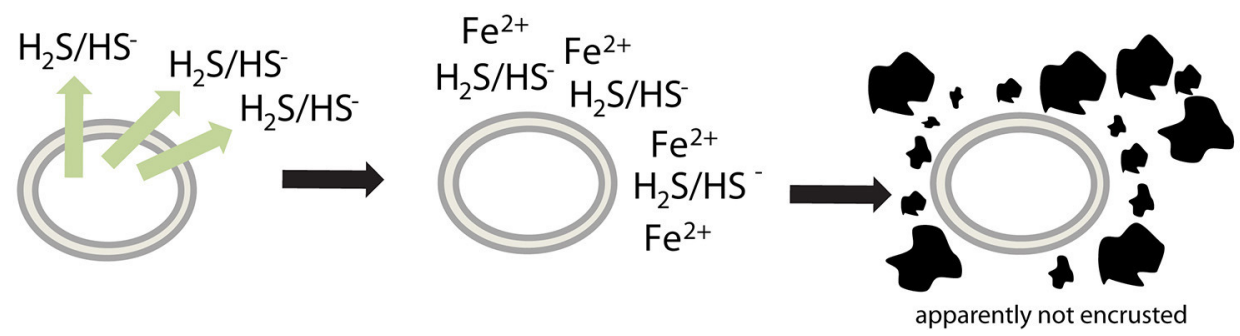

FIGURE 1 | Potential mechanisms for the different biomineralization patterns observed in sulfate-reducing microorganisms. Extracellular iron sulfides, made of mackinawite, and/or greigite, are either $\mathbf{( A )}$ closely associated with cells or (B) loosely aggregated outside cells. (A) If soluble Fe $2+$ is at proximity of cells (or is added to the culture medium before inoculation), it could bind to negatively charged cell surfaces. When sulfide is produced, it could then react with Fe bound to the cell walls, thus forming mineral crusts. Observations in microbial cultures indicate a difference in encrustation between Gram + and Gram - bacteria, suggesting that the binding sites for Fe are located on membranes. However, this question requires more investigation. (B) If soluble Fe ${ }^{2+}$ is at distance from cells then it could precipitate with sulfide without binding to cells. Extracellular polymers have a potential effect on mineral morphology and structure.

(White, 2009), as well as for the distinction between different various compositions of mackinawite and greigite (Bourdoiseau et al., 2008, 2011). Synchrotron X-ray methods, such as X-ray microscopy coupled to XAS may provide details about the microbe-mineral interface at the microscale that are overlooked in bulk studies (Templeton and Knowles, 2009). In the specific case of iron sulfide minerals, soft X-ray scanning transmission $\mathrm{X}$-ray microscopy (STXM) can provide the distribution of C, Fe, and S (Behrens et al., 2012; Cosmidis and Benzerara, 2014). Using soft or hard X-rays, X-ray absorption near-edge structure (XANES), also called near-edge $\mathrm{x}$-ray absorption fine structure (NEXAFS), spectroscopy can resolve the characterization of major biomolecules, such as lipids, polysaccharides and proteins, and the oxidation state of $\mathrm{Fe}$ and $\mathrm{S}$ and the associated mineralogy at the sub-micron scale, respectively (Templeton and Knowles, 2009). As newly precipitated iron sulfide particles are generally in the nm-size range, transmission electron microscopy (TEM) imaging and associated techniques, such as electron energy loss spectroscopy (EELS) and SAED, are essential to characterize the morphology and crystal structure of sulfide mineral crystals at the sub-micron scale (Posfai et al., 2013a). While bulk sulfur isotopic analyses provide the best line of evidence regarding the provenance of sulfide in sulfide minerals, e.g., chemical sulfide vs. sulfide from sulfate reduction or from sulfur disproportionation (Chambers and Trudinger, 1979; Zopfi et al., 2008), considerable variations in isotopic compositions between-and even within-individual pyrite grains can occur (Kohn et al., 1998). In future studies, more spatially precise work using SIMS and nanoSIMS may provide critical information at the sub-micron scale to understand small spatial scale isotope fractionation and its possible causes (Fike et al., 2008; Orphan and House, 2009; Wacey et al., 2010). In highly resolved elemental analyses, co-localization of elements (especially C, N, Fe, S) must be considered. For example, nano-scale chemical mapping of organic carbon and nitrogen has detected relict pyrite framboids likely formed in microbial biofilms in larger pyrite grains (Wacey et al., 2015). In culture experiments, abiotic controls where $\mathrm{pH}, \mathrm{Eh}$, and reactant supply-including sulfide oxidation intermediates-are accurately controlled or quantified are critical to constraining unambiguous biotic influence on mineral rates of formation or morphology. Regarding rates of mineral formation, one study supports the conclusion that SRP may increase them (Mohagheghi et al., 1985), and that pyrite formation might be accelerated by $\mathrm{S}(0)$-disproportionating microorganisms (Canfield et al., 1998). Nevertheless, more studies with a greater variety of microorganisms and 
conditions should be performed to confirm or constrain this result.

If the goal is to arrive at a better understanding of the effects SRP and other microbes have on the formation of extracellular metal sulfides in natural environments, the "holy grail" could be described as studies that link microbial phylogeny and physiology with mineralogy, mineral morphology, rates of mineral formation, and isotope and element chemistry. Our understanding of the evolution of the Earth's surface environment is mainly based on analyses of iron sulfides preserved in ancient or modern sediments. Additionally the presence of pyritized organisms in the sedimentary record of Archaean to Jurassic age implies a potential role for Fe sulfides in the preservation of micro- and macrofossils (Sagemann et al., 1999; Grimes et al., 2001; Schieber, 2002; Cosmidis et al., 2013; Vietti et al., 2015). Deciphering the role of microorganisms in the formation of sulfide minerals is therefore crucial to better constrain the evolution of the biogeochemical cycles of $\mathrm{Fe}, \mathrm{S}$, and $\mathrm{C}$.

\section{CONCLUDING REMARKS}

Sulfide minerals are of great importance for diverse fields of research, e.g., paleontology and reconstruction of past environments, material sciences, and the potential use of sulfide minerals for industrial applications, and economic geology. Two mechanisms of extracellular, biologically induced mineralization have been established: (1) SRP, and potentially other microorganisms, produce free sulfide, which reacts abiotically with dissolved metals to form sulfide minerals, and

\section{REFERENCES}

Allègre, C. J., Poirier, J. P., Humler, E., and Hofmann, A. W. (1995). The chemical composition of the Earth. Earth Planet. Sci. Lett. 134, 515-526.

Andres, R., and Kasgnoc, A. (1998). A time-averaged inventory of subaerial volcanic sulfur emissions. J. Geophys. Res. 103, 25251-25261.

Baas Becking, L. G. M., and Moore, D. (1961). Biogenic sulfides. Econ. Geol. 56, 259-272.

Bak, F., and Pfennig, N. (1987). Chemolithotrophic growth of Desulfovibrio sulfodismutans sp. nov. by disproportionation of inorganic sulfur compounds. Arch. Microb. 147, 184-189.

Bazylinski, D. A., Frankel, R. B., Heywood, B. R., Mann, S., King, J. W., Donaghay, P. L., et al. (1995). Controlled biomineralization of magnetite $\left(\mathrm{Fe}_{3} \mathrm{O}_{4}\right)$ and greigite $\left(\mathrm{Fe}_{3} \mathrm{~S}_{4}\right)$ in a magnetotactic bacterium. Appl. Environ. Microbiol. 61, 3232-3239.

Behrens, S., Kappler, A., and Obst, M. (2012). Linking environmental processes to the in situ functioning of microorganisms by high-resolution secondary ion mass spectrometry (NanoSIMS) and scanning transmission X-ray microscopy (STXM). Environ. Microbiol. 14, 2851-2869. doi: 10.1111/j.14622920.2012.02724.X

Beijerinck, W. M. (1895). Ueber Spirillum desulfuricans als Ursache von Sulfatreduktion. Zentralbl. Bakteriol. 1, 1-9, 49-59, 104-114.

Benning, L. G., Wilkin, R. T., and Konhauser, K. O. (1999). "Iron monosulphide stability: experiments with sulphate-reducing bacteria," in International Symposium on the Geochemistry of Earth's surface, ed H. Armannsson (Reykjavik: Balkema), 429-432.

Berner, R. A. (1982). Burial of organic carbon and pyrite sulfur in the modern ocean: its geochemical and environmental significance. Am. J. Sci. 282, 451-473. doi: 10.2475/ajs.282.4.451
(2) the association of iron with their cell walls and EPS, which then react with sulfide on these surfaces to form metal sulfide minerals. These data, however, do not preclude the possibility that microbes play a more direct role in extracellular iron sulfide formation, perhaps in a manner similar to the intracellular metal sulfide formation found in MTB. The limits of analytical tools and resolution faced by previous investigators may have hindered their ability to better characterize the mineral phases observed during laboratory experiments, but recent advances may provide a timely opportunity to revisit this long-standing question. We suggest that in order to fully consider the microbial role in the formation of metal sulfides, a structured approach that queries both microbial processes and minerals in culture, looks for evidence in natural environments, and attempts to link microbial processes and metal sulfides across spatial scales should be followed. Such an approach is likely to be both challenging and enlightening.

\section{AUTHOR CONTRIBUTIONS}

All authors listed, have made substantial, direct and intellectual contribution to the work, and approved it for publication.

\section{ACKNOWLEDGMENTS}

This material is based upon work supported by the National Science Foundation under Grant No. 1344241. We thank Alyssa J. Findlay and Elizabeth D. Swanner for providing comments and suggestions regarding the manuscript.

Berner, R. A. (1984). Sedimentary pyrite formation: An update. Geochim. Cosmochim. Acta 48, 605-615.

Beveridge, T. J. (1989). Role of cellular design in metal accumulation and mineralization. Annu. Rev. Microbiol. 43, 147-171.

Bourdoiseau, J. A., Jeannin, M., Remazeilles, C., Sabota, R., and Refait, P. (2011). The transformation of mackinawite into greigite studied by Raman spectroscopy. J. Raman Spectrosc. 42, 496-504. doi: 10.1002/jrs.2729

Bourdoiseau, J. A., Jeannin, M., Sabot, R., Remazeilles, C., and Refait, P. (2008). Characterisation of mackinawite by Raman spectroscopy: effects of crystallisation, drying and oxidation. Corros. Sci. 50, 3247-3255. doi: 10.1016/j.corsci.2008.08.041

Braissant, O., Decho, A. W., Dupraz, C., Glunk, C., Przekop, K. M., and Visscher, P. T. (2007). Exopolymeric substances of sulfate-reducing bacteria: interactions with calcium at alkaline $\mathrm{pH}$ and implication for formation of carbonate minerals. Geobiology 5, 401-411. doi: 10.1111/j.1472-4669.2007. 00117.x

Burns, S. J., McKenzie, J. A., and Vasconcelos, C. (2000). Dolomite formation and biogeochemical cycles in the phanerozoic. Sedimentology 47, 49-61. doi: 10.1046/j.1365-3091.2000.00004.x

Canfield, D. E., Stewart, F. J., Thamdrup, B., De Brabandere, L., Dalsgaard, T., Delong, E. F., et al. (2010). A cryptic sulfur cycle in oxygenminimum-zone waters off the Chilean coast. Science 330, 1375-1378. doi: 10.1126/science.1196889

Canfield, D. E., Thamdrup, B., and Fleischer, S. (1998). Isotope fractionation and sulfur metabolism by pure and enrichment cultures of elemental sulfurdisproportionating bacteria. Limnol. Oceanogr. 43, 253-264.

Chambers, L., and Trudinger, P. (1979). Microbiological fractionation of stable sulfur isotopes: a review and critique. Geomicrobiol. J. 1, 249-293. doi: $10.1080 / 01490457909377735$ 
Cosmidis, J., and Benzerara, K. (2014). "Soft X-ray scanning transmission spectromicroscopy," in Biomineralization Sourcebook: Characterization of Biominerals and Biomimetic Materials, eds E. DiMasi and L. B. Gower ( London: CRC Press), 115-133.

Cosmidis, J., Benzerara, K., Gheerbrant, E., Esteve, I., Bouya, B., and Amaghzaz, M. (2013). Nanometer-scale characterization of exceptionally preserved bacterial fossils in Paleocene phosphorites from Ouled Abdoun (Morocco). Geobiology 11, 139-153. doi: 10.1111/gbi.12022

Donald, R., and Southam, G. (1999). Low temperature anaerobic bacterial diagenesis of ferrous monosulfide to pyrite. Geochim. Cosmochim. Acta 63, 2019-2023.

Druschel, G. K., Labrenz, M., Thomsen-Ebert, T., Fowle, D. A., and Banfield, J. F. (2002). Geochemical modeling of $\mathrm{ZnS}$ in biofilms: an example of ore depositional processes. Econ. Geol. 97, 1319-1329. doi: 10.2113/gsecongeo.97.6.1319

Elderfield, H., and Schultz, A. (1996). Mid-ocean ridge hydrothermal fluxes and the chemical composition of the ocean. Annu. Rev. Earth Planet. Sci. 24, 191-224.

Farina, M., Esquivel, D. M. S., and De Barros, H. G. P. L. (1990). Magnetic ironsulphur crystals from a magnetotactic microorganism. Nature 343, 256-258. doi: $10.1038 / 343256 a 0$

Ferris, F. G., Fyfe, W. S., and Beveridge, T. J. (1987). Bacteria as nucleation sites for authigenic minerals in a metal-contaminated lake sediment. Chem. Geol. 63, 225-232.

Fike, D. A., Gammon, C. L., Ziebis, W., and Orphan, V. J. (2008). Micronscale mapping of sulfur cycling across the oxycline of a cyanobacterial mat: a paired nanoSIMS and CARD-FISH approach. ISME J. 2, 749-759. doi: 10.1038/ismej.2008.39

Finster, K., Liesack, W., and Thamdrup, B. (1998). Elemental sulfur and thiosulfate disproportionation by Desulfocapsa sulfoexigens sp nov, a new anaerobic bacterium isolated from marine surface sediment. Appl. Environ. Microbiol. 64, 119-125.

Fortin, D., and Beveridge, T. J. (1997). Microbial sulfate reduction within sulfidic mine tailings: formation of diagenetic Fe sulfides. Geomicrobiol. J. 14, 1-21. doi: 10.1080/01490459709378030

Fortin, D., Southam, G., and Beveridge, T. J. (1994). Nickel sulfide, iron-nickel sulfide and iron sulfide precipitation by a newly isolated Desulfotomaculum species and its relation to nickel resistance. FEMS Microbiol. Ecol. 14, 121-132.

Foti, M., Sorokin, D. Y., Lomans, B., Mussman, M., Zacharova, E. E., Pimenov, N. V., et al. (2007). Diversity, activity, and abundance of sulfate-reducing bacteria in saline and hypersaline soda lakes. Appl. Environ. Microbiol. 73, 2093-2100. doi: 10.1128/AEM.02622-06

Frank, K. L., Rogers, D. R., Olins, H. C., Vidoudez, C., and Girguis, P. R. (2013). Characterizing the distribution and rates of microbial sulfate reduction at Middle Valley hydrothermal vents. ISME J. 7, 1391-1401. doi: 10.1038/ismej.2013.17

Freke, A. M., and Tate, D. (1961). The formation of magnetic iron sulfide by bacterial reduction of iron solutions. J. Biochem. Microbiol. 3, 29-39.

Gallagher, K. L., Kading, T. J., Braissant, O., Dupraz, C., and Visscher, P. T. (2012). Inside the alkalinity engine: the role of electron donors in the organomineralization potential of sulfate-reducing bacteria. Geobiology 10, 518-530. doi: 10.1111/j.1472-4669.2012.00342.x

Gramp, J. P., Bigham, J. M., Jones, F. S., and Tuovinen, O. H. (2010). Formation of Fe-sulfides in cultures of sulfate-reducing bacteria. J. Hazard. Mater. 175, 1062-1067. doi: 10.1016/j.jhazmat.2009.10.119

Gramp, J. P., Wang, H. M., Bigham, J. M., Jones, F. S., and Tuovinen, O. H. (2009). Biogenic synthesis and reduction of Fe(III)-hydroxysulfates. Geomicrobiol. J. 26, 275-280. doi: 10.1080/01490450902892597

Griesbeck, C., Hauska, G., and Schütz, M. (2000). "Biological sulfide oxidation: sulfide-quinone reductase (SQR), the primary reaction," in Recent Research Developments in Microbiology, ed S. G. Pandalai (Trivandrum: Research Signpost), 179-203.

Grimes, S. T., Brock, F., Rickard, D., Davies, K. L., Edwards, D., Briggs, D. E., et al. (2001). Understanding fossilization: experimental pyritization of plants. Geology 29, 123-126. doi: 10.1130/00917613(2001)029<0123:UFEPOP>2.0.CO;2

Herbert, R. B. Jr., Benner, S. G., Pratt, A. R., and Blowes, D. W. (1998). Surface chemistry and morphology of poorly crystalline iron sulfides precipitated in media containing sulfate-reducing bacteria. Chem. Geol. 144, 87-97.
Holmkvist, L., Ferdelman, T. G., and Jørgensen, B. B. (2011). A cryptic sulfur cycle driven by iron in the methane zone of marine sediment (Aarhus Bay, Denmark). Geochim. Cosmochim. Acta 75, 3581-3599. doi: 10.1016/j.gca.2011.03.033

Jørgensen, B. B. (1982). Mineralization of organic matter in the sea bed-the role of sulphate reduction. Nature 296, 643-645. doi: 10.1038/296643a0

Jørgensen, B. B., Isaksen, M. F., and Jannasch, H. W. (1992). Bacterial sulfate reduction above $100^{\circ} \mathrm{C}$ in deep-sea hydrothermal vent sediments. Science 258, 1756-1757. doi: 10.1126/science.258.5089.1756

Jørgensen, B. B., and Nelson, D. C. (2004). Sulfide oxidation in marine sediments: geochemistry meets microbiology. Geol. Soc. Am. Spec. Pap. 379, 63-81. doi: 10.1130/0-8137-2379-5.63

Karr, E. A., Ng, J. M., Belchik, S. M., Sattley, W. M., Madigan, M. T., and Achenbach, L. A. (2006). Biodiversity of methanogenic and other archaea in the permanently frozen lake Fryxell, Antarctica. Appl. Environ. Microbiol. 72, 1663-1666. doi: 10.1128/AEM.72.2.1663-1666.2006

Kato, S., Ikehata, K., Shibuya, T., Urabe, T., Ohkuma, M., and Yamagishi, A. (2015). Potential for biogeochemical cycling of sulfur, iron and carbon within massive sulfide deposits below the seafloor. Environ. Microbiol. 17, 1817-1835. doi: $10.1111 / 1462-2920.12648$

Kim, Y., Lee, Y., and Roh, Y. (2015). Microbial synthesis of iron sulfide (FeS) and iron carbonate $\left(\mathrm{FeCO}_{3}\right)$ nanoparticles. J. Nanosci. Nanotechnol. 15, 5794-5797. doi: 10.1166/jnn.2015.10457

Kohn, M. J., Riciputi, L. R., Stakes, D., and Orange, D. L. (1998). Sulfur isotope variability in biogenic pyrite: reflections of heterogeneous bacterial colonization? Am. Mineral. 83, 1454-1468. doi: 10.2138/am-1998-11-1234

Kormas, K. A., Tivey, M. K., Von Damm, K., and Teske, A. (2006). Bacterial and archaeal phylotypes associated with distinct mineralogical layers of a white smoker spire from a deep-sea hydrothermal vent site ( 9 degrees N, East Pacific Rise). Environ. Microbiol. 8, 909-920. doi: 10.1111/j.1462-2920.2005. 00978.x

Labrenz, M., and Banfield, J. F. (2004). Sulfate-reducing bacteria-dominated biofilms that precipitate $\mathrm{ZnS}$ in a subsurface circumneutral-pH mine drainage system. Microb. Ecol. 47, 205-217. doi: 10.1007/s00248-003-1025-8

Labrenz, M., Druschel, G. K., Thomsen-Ebert, T., Gilbert, B., Welch, S. A., Kemner, K. M., et al. (2000). Formation of sphalerite ( $\mathrm{ZnS})$ deposits in natural biofilms of sulfate-reducing bacteria. Science 290, 1744-1747. doi: 10.1126/science.290.5497.1744

Lefevre, C. T., and Bazylinski, D. A. (2013). Ecology, diversity, and evolution of magnetotactic bacteria. Microbiol. Mol. Biol. R. 77, 497-526. doi: 10.1128/MMBR.00021-13

Lefevre, C. T., Menguy, N., Abreu, F., Lins, U., Posfai, M., Prozorov, T., et al. (2011). A cultured greigite-producing magnetotactic bacterium in a novel group of sulfate-reducing bacteria. Science 334, 1720-1723. doi: $10.1126 /$ science. 1212596

Leloup, J., Fossing, H., Kohls, K., Holmkvist, L., Borowski, C., and Jørgensen, B. B. (2009). Sulfate-reducing bacteria in marine sediment (Aarhus Bay, Denmark): abundance and diversity related to geochemical zonation. Environ. Microbiol. 11, 1278-1291. doi: 10.1111/j.1462-2920.2008.01855.x

Li, Y. L., Vali, H., Sears, S. K., Yang, J., Deng, B., and Zhang, C. L. (2004). Iron reduction and alteration of nontronite NAu-2 by a sulfate-reducing bacterium. Geochim. Cosmochim. Acta 68, 3251-3260. doi: 10.1016/j.gca.2004.03.004

Li, Y. L., Vali, H., Yang, J., Phelps, T. J., and Zhang, C. L. (2006). Reduction of iron oxides enhanced by a sulfate-reducing bacterium and biogenic $\mathrm{H}_{2} \mathrm{~S}$. Geomicrobiol. J. 23, 103-117. doi: 10.1080/01490450500533965

Maclean, L. C. W., Pray, T. J., Onstott, T. C., Brodie, E. L., Hazen, T. C., and Southam, G. (2007). Mineralogical, chemical and biological characterization of an anaerobic biofilm collected from a borehole in a deep gold mine in South Africa. Geomicrobiol. J. 24, 491-504. doi: 10.1080/01490450701572416

Maclean, L. C. W., Tyliszczak, T., Gilbert, P. U. P. A., Zhou, D., Pray, T. J., Onstott, T. C., et al. (2008). A high-resolution chemical and structural study of framboidal pyrite formed within a low-temperature bacterial biofilm. Geobiology 6, 471-480. doi: 10.1111/j.1472-4669.2008.00174.x

Miller, L. P. (1950). Tolerance of sulfate-reducing bacteria to hydrogen sulfide. Contrib. Boyce Thompson Inst. 16, 73-83.

Mohagheghi, A., Updegraff, D. M., and Goldhaber, M. B. (1985). The role of sulfate-reducing bacteria in the deposition of sedimentary uranium ores. Geomicrobiol. J. 4, 153-173. 
Nakagawa, T., Ishibashi, J.-I., Maruyama, A., Yamanaka, T., Morimoto, Y., Kimura, H., et al. (2004). Analysis of dissimlatory sulfite reductase and 16S rRNA gene fragments from deep-sea hydrothermal sites of the Suiyo seamont, Izu-Bonin-arc, Western Pacific. Appl. Environ. Microbiol. 70, 393-403. doi: 10.1128/AEM.70.1.393-403.2004

Neal, A. L., Techkarnjanaruk, S., Dohnalkova, A., McCready, D., Peyton, B. M., and Geesey, G. G. (2001). Iron sulfides and sulfur species produced at hematite surfaces in the presence of sulfate-reducing bacteria. Geochim. Cosmochim. Acta 65, 223-235. doi: 10.1016/S0016-7037(00)00537-8

Orphan, V., and House, C. (2009). Geobiological investigations using secondary ion mass spectrometry: microanalysis of extant and paleo-microbial processes. Geobiology 7, 360-372. doi: 10.1111/j.1472-4669.2009.00201.x

Posfai, M., Buseck, P. R., Bazylinski, D. A., and Frankel, R. B. (1998). Reaction sequence of iron sulfide minerals in bacteria and their use as biomarkers. Science 280, 880-883. doi: 10.1126/science.280.5365.880

Posfai, M., Kasama, T., and Dunin-Borkowski, R. E. (2013a). "Biominerals at the nanoscale: transmission electron microscopy methods for studying the special properties of biominerals," in Minerals at the Nanoscale, eds F. Nieto, K. T. V. Livi, and R. Oberti (London: Mineralogical Society of Great Britain and Ireland), 377-435.

Posfai, M., Lefevre, C. T., Trubitsyn, D., Bazylinski, D. A., and Frankel, R. B. (2013b). Phylogenetic significance of composition and crystal morphology of magnetosome minerals. Front. Microbiol. 4:344. doi: 10.3389/fmicb.2013.00344

Prange, A., Engelhardt, H., Truper, H. G., and Dahl, C. (2004). The role of the sulfur globule proteins of Allochromatium vinosum: mutagenesis of the sulfur globule protein genes and expression studies by real-time RT-PCR. Arch. Microbiol. 182, 165-174. doi: 10.1007/s00203-004-0683-3

Rabus, R., Hansen, T., and Widdel, F. (2013). "Dissimilatory sulfate- and sulfurreducing prokaryotes," in The Prokaryotes, eds E. Rosenberg, E. Delong, S. Lory, E. Stackebrandt, and F. Thompson (Heidelberg: Springer), 309-404.

Ramamoorthy, S., Piotrowski, J. S., Langner, H. W., Holben, W. E., Morra, M. J., and Rosenzweig, R. F. (2009). Ecology of sulfate-reducing bacteria in an iron-dominated, mining-impacted freshwater sediment. J. Environ. Qual. 38, 675-684. doi: 10.2134/jeq2007.0577

Ravenschlag, K., Sahm, K., Knoblauch, C., Jørgensen, B. B., and Amann, R. (2000). Community structure, cellular rRNA content, and activity of sulfate-reducing bacteria in marine Arctic sediments. Appl. Environ. Microbiol. 66, 3592-3602. doi: 10.1128/AEM.66.8.3592-3602.2000

Rickard, D. T. (1969). The microbiological formation of iron sulphides. Stockholm Contrib. Geol. 20, 49-66.

Rickard, D. T. (2012a). "Metastable sedimentary iron sulfides," in Developments in Sedimentology, ed D. T. Rickard (Oxford: Elsevier), 195-231.

Rickard, D. T. (2012b). "Microbial sulfate reduction in sediments," in Developments in Sedimentology, ed D. T. Rickard (Oxford: Elsevier), 319-351.

Rickard, D. T. (2012c). "Sedimentary pyrite," in Developments in Sedimentology, ed D. T. Rickard (Oxford: Elsevier), 233-285.

Robador, A., Jungbluth, S. P., Larowe, D., Bowers, R., Rappe, M., Amend, J., et al. (2015). Activity and phylogenetic diversity of sulfate-reducing microorganisms in low-temperature subsurface fluids within the upper oceanic crust. Front. Microbiol. 5:748. doi: 10.3389/fmicb.2014.00748

Sagemann, J., Bale, S. J., Briggs, D. E., and Parkes, R. J. (1999). Controls on the formation of authigenic minerals in association with decaying organic matter: an experimental approach. Geochim. Cosmochim. Acta 63, 1083-1095. doi: 10.1016/s0016-7037(99)00087-3

Sass, H., Ramamoorthy, S., Yarwood, C., Langner, H., Schumann, P., Kroppenstedt, R. M., et al. (2009). Desulfovibrio idahonensis sp. nov., sulfate-reducing bacteria isolated from a metal(loid)-contaminated freshwater sediment. Int. J. Syst. Evol. Microbiol. 59, 2208-2214. doi: 10.1099/ijs.0.016709-0

Schieber, J. (2002). Sedimentary pyrite: a window into the microbial past. Geology 30, 531-534. doi: 10.1130/0091-7613(2002)030<0531:SPAWIT > 2.0.CO;2

Schoonen, MaA. (2004). Mechanisms of sedimentary pyrite formation. Geol. Soc. Am. Spec. Pap. 379, 117-134. doi: 10.1130/0-8137-2379-5.117

Siebenthal, C. E. (1915). Origin of the Zinc and Lead Deposits of the Joplin Region, Missouri, Kansas, and Oklahoma. Washington, DC: Govt. Print. Off.
Simmons, S. L., Sievert, S. M., Frankel, R. B., Bazylinski, D. A., and Edwards, K. J. (2004). Spatiotemporal distribution of marine magnetotactic bacteria in a seasonally stratified coastal salt pond. Appl. Environ. Microbiol. 70, 6230-6239. doi: 10.1128/AEM.70.10.6230-6239.2004

Temple, K. L., and Le Roux, N. W. (1964). Syngenesis of sulfide ores: desorption of adsorbed metal ions and their precipitation as sulfides. Econ. Geol. 59, 647-655. doi: 10.2113/gsecongeo.59.4.647

Templeton, A., and Knowles, E. (2009). Microbial transformations of minerals and metals: recent advances in geomicrobiology derived from synchrotron-based X-ray spectroscopy and X-ray microscopy. Annu. Rev. Earth Planet. Sci. 37, 367-391. doi: 10.1146/annurev.earth.36.031207.124346

Thamdrup, B., Finster, K., Hansen, J. W., and Bak, F. (1993). Bacterial disproportionation of elemental sulfur coupled to chemical reduction of iron or manganese. Appl. Environ. Microbiol. 59, 101-108.

Trudinger, P. A., Chambers, L. A., and Smith, J. W. (1985). Low-temperature sulphate reduction: biological versus abiological. Can. J. Earth Sci. 22, 1910-1918.

Vietti, L. A., Bailey, J. V., Fox, D., and Rogers, R. R. (2015). Rapid formation of framboidal sulfides on bone surfaces from a simulated marine carcass fall. Palaios 30, 327-334. doi: 10.2110/palo.2014.027

Wacey, D., Kilburn, M. R., Saunders, M., Cliff, J. B., Kong, C., Liu, A. G., et al. (2015). Uncovering framboidal pyrite biogenicity using nano-scale $\mathrm{CN}_{\text {org }}$ mapping. Geology 43, 27-30. doi: 10.1130/G36048.1

Wacey, D., McLoughlin, N., Whitehouse, M. J., and Kilburn, M. R. (2010). Two coexisting sulfur metabolisms in a ca. 3400 Ma sandstone. Geology 38, 1115-1118. doi: 10.1130/G31329.1

Watson, J. H. P., Cressey, B. A., Roberts, A. P., Ellwood, D. C., Charnock, J. M., and Soper, A. K. (2000). Structural and magnetic studies on heavy-metal-adsorbing iron sulphide nanoparticles produced by sulphate-reducing bacteria. J. Magn. Magn. Mater. 214, 13-30. doi: 10.1016/S0304-8853(00)00025-1

White, S. N. (2009). Laser Raman spectroscopy as a technique for identification of seafloor hydrothermal and cold seep minerals. Chem. Geol. 259, 240-252. doi: 10.1016/j.chemgeo.2008.11.008

Widdel, F., and Bak, F. (1992). "Gram-negative mesophilic sulfate-reducing bacteria," in The Prokaryotes, eds A. Balows, H. Trüper, M. Dworkin, W. Harder, and K. H.Schleifer (New York, NY: Springer), 3352-3378.

Williams, K. H., Ntarlagiannis, D., Slater, L. D., Dohnalkova, A., Hubbard, S. S., and Banfield, J. F. (2005). Geophysical imaging of stimulated microbial biomineralization. Environ. Sci. Technol. 39, 7592-7600. doi: $10.1021 /$ es0504035

Zammit, C. M., Shuster, J. P., Gagen, E. J., and Southam, G. (2015). The geomicrobiology of supergene metal deposits. Elements 11, 337-342. doi: 10.2113/gselements.11.5.337

Zhou, C., Vannela, R., Hayes, K. F., and Rittmann, B. E. (2014). Effect of growth conditions on microbial activity and iron-sulfide production by Desulfovibrio vulgaris. J. Hazard. Mater. 272, 28-35. doi: 10.1016/j.jhazmat.2014.02.046

Zopfi, J., Böttcher, M. E., and Jørgensen, B. B. (2008). Biogeochemistry of sulfur and iron in Thioploca-colonized surface sediments in the upwelling area off central Chile. Geochim. Cosmochim. Acta 72, 827-843. doi: 10.1016/j.gca.2007.11.031

Zopfi, J., Ferdelman, T., and Fossing, H. (2004). Distribution and fate of sulfur intermediates - sulfite, tetrathionate, thiosulfate, and elemental sulfur - in marine sediments. Geol. Soc. Am. Spec. Pap. 379, 97-116. doi: 10.1130/0-81372379-5.97

Conflict of Interest Statement: The authors declare that the research was conducted in the absence of any commercial or financial relationships that could be construed as a potential conflict of interest.

Copyright (๑) 2016 Picard, Gartman and Girguis. This is an open-access article distributed under the terms of the Creative Commons Attribution License (CC BY). The use, distribution or reproduction in other forums is permitted, provided the original author(s) or licensor are credited and that the original publication in this journal is cited, in accordance with accepted academic practice. No use, distribution or reproduction is permitted which does not comply with these terms. 